This item was submitted to Loughborough's Research Repository by the author.

Items in Figshare are protected by copyright, with all rights reserved, unless otherwise indicated.

\title{
Why firewood? Exploring the co-benefits, socio-ecological interactions and indigenous knowledge surrounding cooking practice in rural Nepal
}

\section{PLEASE CITE THE PUBLISHED VERSION}

https://doi.org/10.1016/j.erss.2021.101932

\section{PUBLISHER}

Elsevier

VERSION

AM (Accepted Manuscript)

\section{PUBLISHER STATEMENT}

This paper was accepted for publication in the journal Energy Research and Social Science and the definitive published version is available at https://doi.org/10.1016/j.erss.2021.101932

LICENCE

CC BY-NC-ND 4.0

\section{REPOSITORY RECORD}

Bharadwaj, Bishal, David Pullar, Long Seng To, and Jon Leary. 2021. "Why Firewood? Exploring the Cobenefits, Socio-ecological Interactions and Indigenous Knowledge Surrounding Cooking Practice in Rural Nepal". Loughborough University. https://hdl.handle.net/2134/14192456.v1. 
Bharadwaj, Bishal, David Pullar, Long Seng To, and Jon Leary. "Why Firewood? Exploring the CoBenefits, Socio-Ecological Interactions and Indigenous Knowledge Surrounding Cooking Practice in Rural Nepal." Energy Research \& Social Science, https://doi.org/10.1016/j.erss.2021.101932 (accepted manuscript)

\section{Why Firewood? Exploring the co-benefits, socio-ecological interactions and indigenous knowledge surrounding cooking practice in rural Nepal}

\section{Introduction}

Cooking with firewood is an age-old social practice. As it has been embedded within society for so long, households have developed this practice in synergy with other livelihood strategies. For example, if a household plants a tree, they can use the leaves as fodder, dead branches as cooking fuel and then the firewood ash as fertiliser or pesticide. These linkages to cooking practices can be referred to as co-benefits [1]. These practices become embedded within the local culture and are passed down through generations as indigenous knowledge [2]. Understanding these co-benefits and indigenous knowledges are essential aspects of understanding sustainable livelihoods [3].

However, Traditional Cooking Practice (TCP) relies upon solid fuel, which creates indoor air pollution that claims an estimated 4.3 million lives globally every year [4]. It also has significant environmental consequences: not only does it result in deforestation and forest degradation, but it is also a source of black carbon and carbon dioxide emissions, both of which contribute to climate change [5-7]. In 2015, the Government of Nepal (GoN) aimed to reduce the proportion of households relying upon solid fuels, such as firewood, for cooking to $10 \%$ by 2030 [8]. This target was revised to $30 \%$ in 2017 [9], likely because a $5 \%$ annual reduction was unrealistic. Several interventions are in place, including a nationwide social mobilisation program for improved cookstoves, subsidised household biogas installations, and awareness campaigns from as early as 1990 . These programs were expected to boost the transition to clean cooking practices in Nepal. 
Bharadwaj, Bishal, David Pullar, Long Seng To, and Jon Leary. "Why Firewood? Exploring the CoBenefits, Socio-Ecological Interactions and Indigenous Knowledge Surrounding Cooking Practice in Rural Nepal." Energy Research \& Social Science, https://doi.org/10.1016/i.erss.2021.101932 (accepted manuscript)

Despite these efforts, the number of households using Modern Cooking Solutions (MCS) has remained low [10]. In 2011, fewer than $10 \%$ of the population had access to clean cooking in more than half of Nepal's 75 districts [11]. Contrary to expectations, household use of cow dung in the Central and Eastern Terai of Nepal has increased from 2001 to 2010 . In 2015, around 3\% of households used biogas for cooking, whereas for cow dung, it was about $10 \%$ [12]. All of these figures demonstrate the ineffectiveness of the current approach to promoting clean cooking in Nepal.

'What prevents MCS uptake in Nepal?' is an important policy question. In response to this question, one can prepare a long list of barriers in Nepal, which will no doubt have a lot in common with those seen in other developing countries. However, we focus this discussion onto the weakness in our understanding of practices that fails to internalise the social context within which households practice their livelihoods and therefore results in the development of ineffective policies. First, the current approach to MCS promotion is centralised and supplydriven, such as distributing a set of supposedly 'improved' cookstoves [13]. This is illustrated by critiques of the approach of the Belgian NGO, BIKAS, during the 1990s [14], where any outside supply of western practices was considered as development. It is difficult for these programmes to target diverse social settings, as a particular type of MCS is chosen centrally and then pushed toward the rest of Nepal, without taking into consideration local needs and aspirations. For instance, GoN selected biogas for a clean cooking subsidy programme to offset the high installation cost. Biogas provides clean energy from organic feedstocks such as cow manure and therefore, biogas was promoted for its compatibility with agricultural livelihoods [15]. Although it reduces firewood use, burns without smoke, provides manure for agriculture and has negligible operational cost, the technical requirements for biogas 
Bharadwaj, Bishal, David Pullar, Long Seng To, and Jon Leary. "Why Firewood? Exploring the CoBenefits, Socio-Ecological Interactions and Indigenous Knowledge Surrounding Cooking Practice in Rural Nepal." Energy Research \& Social Science, https://doi.org/10.1016/i.erss.2021.101932 (accepted manuscript)

installations (which include having cattle for cow dung, having space to construct digester, and house ownership, i.e those living in rented rooms cannot install this kind of substantial infrastructure) make it unfeasible for the majority of households in Nepal. However, designing a programme with the same subsidy for the entire country does not reflect the diversity in income levels and accessibility seen throughout the country [16]. When we choose to push a single solution or give a fixed amount of subsidy to an accessible village from the central region with many livelihood options and a remote village in the Himalayas with few, or to everyone within the same diverse village, we are likely to face two key limitations.

The first is a techno-economic limitation to address the diverse geophysical and socioeconomic characteristics. For example, biogas may not produce sufficient gas during the winter in the mountainous regions due to the cold climate [17]. This reduced production limits its adoption in the mountains and high hills of Nepal. Meanwhile, the warm plains and lower hills with appropriate climate for biogas are facing rapid urbanisation with declining cattle ownership and the conversion of agricultural land into residential to house the growing population. This has seen a decline in the number of potential biogas adopters. On top of this, $40 \%$ (59\% in Kathmandu, the capital city) of urban dwellers live in rented accommodation [11], where they cannot install this kind of biogas system. What is more, the centralised promotion of just one technology will have a disproportionate effect on some households. For example, the biogas subsidy primarily benefited wealthy households [16]. The benefits of biogas to those with limited economic opportunities are often modest because the opportunity cost of saving their time is low [18], showing that the clean energy transition does not always 
Bharadwaj, Bishal, David Pullar, Long Seng To, and Jon Leary. "Why Firewood? Exploring the CoBenefits, Socio-Ecological Interactions and Indigenous Knowledge Surrounding Cooking Practice in Rural Nepal." Energy Research \& Social Science, https://doi.org/10.1016/j.erss.2021.101932 (accepted manuscript)

generate net benefit for all households [19]. These are just some examples of the technoeconomic limitations of MCS in the diverse social context of Nepal.

The second challenge is the alignment of clean cooking policies with the changing social context and power structures. Technical superiority should not be the only criteria to endorse and implement policy; there should be an appreciation of the diverse social realities, such as cultural power structures and beliefs at the ground level [20,21]. Poor understanding of household needs and aspirations, social structures and expectations often leads to failures during implementation $[22,23]$. Starting a technological push without a proper understanding of the social context creates an incongruity where a solution promoted on technical grounds is inappropriate for the social context. One example of this is toilet fed biogas in Nepal. As ownership of cattle has reduced over the years, the Government of Nepal started to promote toilet fed biogas as an alternative solution. However, cultural resistance to using human excreta as an energy source has been identified, as neighbours of households with toilet-fed biogas have indicated social opposition to this practice. For instance, reluctance to visit a house with toilet-fed biogas or hesitancy to eat food cooked with this fuel has imposed a social cost on adopters. Biogas adoption is skewed toward the rich and high caste [16], hence, linking the toilet to biogas production may challenge their social status in Nepalese societies. Ignoring this cost has led to an overestimation of the potential for this type of biogas.

The promotion of a wider range of MCS and consideration of 'fuel stacking' could facilitate the development of more culturally-appropriate solutions across the country. Despite a high amount of subsidy (roughly 275 USD in 2016) for biogas, adoption has remained low. The uptake of MCS could have been much higher if GoN had included different MCS in the subsidy programme; for example, electric cooking (eCooking) could be 
Bharadwaj, Bishal, David Pullar, Long Seng To, and Jon Leary. "Why Firewood? Exploring the CoBenefits, Socio-Ecological Interactions and Indigenous Knowledge Surrounding Cooking Practice in Rural Nepal." Energy Research \& Social Science, https://doi.org/10.1016/j.erss.2021.101932 (accepted manuscript)

more suitable for remote mountain areas where off-grid micro-hydro plants are in operation. Complete replacement of TCP with a single MCS is challenging because each of these cooking solutions has unique strengths and weaknesses that drive and restrict their uptake in different geographies. Even in areas where MCS are available and affordable, households frequently own more than one cooking option and 'fuel stack' between them [24]. For example, in the high mountain regions, households often use firewood for the majority of cooking and water heating, whilst LPG is used to prepare tea and snacks [25].

It is therefore clear that considering only the benefits of MCS and ignoring the loss of co-benefits from TCP results in unintended consequences and/or low levels of uptake. TCP extends into households' livelihood practices. With limited knowhow of rural livelihoods in diverse socio-cultural settings, these benefits are likely to be overlooked. While considering the benefits of MCS, we must therefore also consider the range of co-benefits associated with the targeted and supposedly 'inferior' traditional practice.

The remainder of this section will provide further background on the socio-economic setting for Nepali rural communities and draw attention to the deficiencies in current strategies for improving clean cooking practices in these communities. The end of this section describes the scope of our research to address these deficiencies, which are explored in the remainder of the paper.

\subsection{Livelihoods and types of cookstoves in rural Nepal}

Although remote rural households still depend on agricultural livelihoods, the trend is rapidly changing due to out-migration and inflow of remittances [26, 27]. Most Nepalese people own their own home (85\% in 2011 [11]), often a small cottage, and engage in subsistence farming (more than 2/3 owned land in 2011 [28]). They are often involved in community activities, such as cooperatives and community forest user groups. Families often rear cattle for milk 
Bharadwaj, Bishal, David Pullar, Long Seng To, and Jon Leary. "Why Firewood? Exploring the CoBenefits, Socio-Ecological Interactions and Indigenous Knowledge Surrounding Cooking Practice in Rural Nepal." Energy Research \& Social Science, https://doi.org/10.1016/j.erss.2021.101932 (accepted manuscript)

and/or goats/pigs/chicken for meat; tend a small vegetable garden (called Kothe Bari) and/or a small farm to cultivate beans, corn and fruits (called Bari); and/or manage farmland (known as Khet) to produce staple foods, such as rice and wheat. Agroforestry, a prevalent practice, supplies fruits, fodder and firewood. However, due to rapid migration to urban and semiurban areas, these practices are diminishing in rural areas. On top of this, the notion of development is understood as following Western and externally-fed practices - a significant driving force behind development practice and social change in Nepal [14].

Rural households usually have more than one cooking stove in their households, which can include MCS such as LPG and biogas [13, 29]. Although each of these cooking stoves has a specific purpose (see Photo-1), they can also be used interchangeably, for example, to be able to cook a larger amount of food for guests.

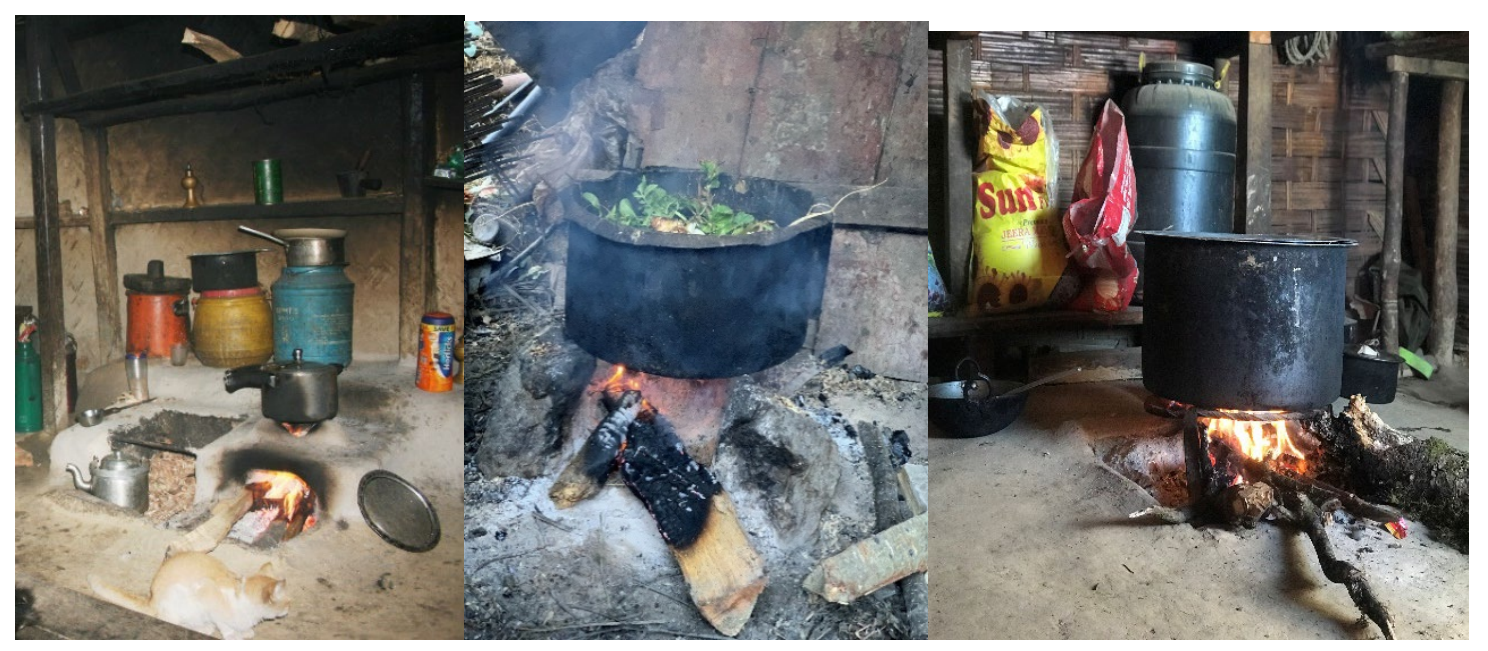

Photo 1: Chulo used for preparing a meal (Left); Ageno outside the house, used for preparing cattle-feed (Middle) Ageno inside the house and used to prepare tea, boil milk/water and also prepare cattle feed (Right) in different locations of Nepal. (Photo Credit: Ramila Bhandari for left and middle and Damber Bista for right)

The first type of cookstove, known as Chulo, is indoor and used for cooking lunch and dinner (see Photo-1, left). This cookstove is modified to suit family size, heating needs, 
Bharadwaj, Bishal, David Pullar, Long Seng To, and Jon Leary. "Why Firewood? Exploring the CoBenefits, Socio-Ecological Interactions and Indigenous Knowledge Surrounding Cooking Practice in Rural Nepal." Energy Research \& Social Science, https://doi.org/10.1016/j.erss.2021.101932 (accepted manuscript)

and the nature of food preparation. Many households add a small appendix known as Bhungro that uses hot charcoal from burned firewood (right side of the Photo-1, Left). A Chamka can adjust the height on the burner to control heat, adjust it to pot size, and manage the flame. Improved Cookstoves (ICS) and MCS generally aim to replace these stoves.

Households can also have another type of traditional stove, commonly outside the house, to prepare animal feed for livestock and prepare alcohol (Photo-1, Middle). Altogether $63 \%$ of Nepali households owned livestock in 2010 [28]. The fuel used in this stove is fast burning biomass, such as waste fodder or cash crop residue mixed with firewood. If the household head is vegetarian, other family members prepare non-vegetarian items in this [outside] stove because people believe that preparing meat inside will offend clan deities [30]. This stove is also used for heating water, preparing a meal for hired daily-wage workers and brewing alcohol.

The third type of cookstove, called Ageno, is less common and used to prepare tea, boil water and milk, and for space heating (Photo-1, Right). Household members typically gather around the Ageno, to chat and enjoy social interaction whilst to warm themselves, in practice known as Aago-tapne.

\subsection{Cooking in the context of socio-ecological systems is poorly understood}

TCP links households to their socio-ecological systems in several ways. Energy and agriculture are essential aspects of rural livelihoods. Rural communities develop their livelihood strategies around these essential components, whilst remaining within accepted social norms [31] - TCP is not an exception. These strategies form the basis for cooking solution choice criteria, consciously or unconsciously; however, current understanding of 
Bharadwaj, Bishal, David Pullar, Long Seng To, and Jon Leary. "Why Firewood? Exploring the CoBenefits, Socio-Ecological Interactions and Indigenous Knowledge Surrounding Cooking Practice in Rural Nepal." Energy Research \& Social Science, https://doi.org/10.1016/j.erss.2021.101932 (accepted manuscript)

these strategies and their socio-ecological interaction is thin [2]. We discuss some of the issues in this section.

The first deficiency is the way current literature views household cooking practices. Previous research has attempted to identify determinants of clean energy adoption [32-35], explore fuel choice behaviour [36-38] or explain cooking as a social practice [39, 40]. However, these studies typically present MCS as a solution by pointing out the deficiencies in TCP. These studies have shown that households near firewood sources are more likely to use TCP and that more impoverished families are more likely to use solid fuels, such as firewood or cowdung [38] and that a combination of factors, such as occupation and income, affect cooking practice [37]. If we assume that deprived households rely on TCP, then we may also assume that adopting MCS is a panacea to their deprivation. However, this is clearly not the case. Existing research often seeks to push MCS by exploring the socioeconomic determinants at the household level, rather than looking into the social constructs of existing practices that make TCP more attractive than MCS. Social context and its structure are community-specific [23, 41], but can provide pragmatic insights into local issues that are often overlooked [42]. It is crucial to address the knowledge gap on the motivations for households to hold onto TCP.

Secondly, the current understanding of the co-benefits of TCP through socioecological interaction is limited. Several studies have tried to explain the advantages of TCP, such as flexibility and cultural compatibility $[23,43]$. Still, they are limited to usage and perceptional values rather than synergies and trade-offs. The current body of cooking fuel literature does not adequately consider the co-benefits, or desirable services, that existing cooking practice offers via interactions with the socio-ecological system and the impacts of 
Bharadwaj, Bishal, David Pullar, Long Seng To, and Jon Leary. "Why Firewood? Exploring the CoBenefits, Socio-Ecological Interactions and Indigenous Knowledge Surrounding Cooking Practice in Rural Nepal." Energy Research \& Social Science, https://doi.org/10.1016/j.erss.2021.101932 (accepted manuscript)

the technological push of MCS on the synergistic relationship between the household and their livelihood. One cannot merely assume that MCS deliver benefits, and TCP causes harm. Ignoring the benefits of TCP on one side and the cost of MCS on another will unfairly tip the balance against TCP. A lack of clear understanding of the indigenous knowledge that accompanies TCP and an explanation of its co-benefits hinders a proper evaluation of the implications of MCS adoption on broader livelihoods.

Thirdly, in socio-ecological systems, social practices shape ecology and vice versa [44]. The socio-ecological impacts of the clean cooking transition are not well known. While excessive emphasis is put on techno-economic benefits, we often forget to look into the social and livelihood impacts of clean cooking adoption, as well as ecological feedback. Moving from TCP to MCS is not a one-way process [45], as illustrated by households returning to cooking with firewood during the 2015 earthquake in Nepal [46]. This raises questions around energy security and the resilience of cooking practices in developing countries like Nepal, where the supply chain of MCS and their underlying energy sources face frequent disruption.

Fourthly, adopting MCS is often accompanied by the sacrifice of important cobenefits. Modernisation influences socio-ecological interactions and indigenous knowledge can evolve around new situations. However, the timescales and conditions under which this evolution can occur are less well known [44]. For example, when LPG replaces firewood, a household might replace firewood smoke with sun-light for drying, however replacing space heating is likely to be more difficult. Failure to understand these trade-offs and the innovation of indigenous practices will lead to a situation where we push MCS with a hidden cost. For example, replacing TCP by LPG in the high altitude areas of Nepal could be beneficial from 
Bharadwaj, Bishal, David Pullar, Long Seng To, and Jon Leary. "Why Firewood? Exploring the CoBenefits, Socio-Ecological Interactions and Indigenous Knowledge Surrounding Cooking Practice in Rural Nepal." Energy Research \& Social Science, https://doi.org/10.1016/j.erss.2021.101932 (accepted manuscript)

an indoor air pollution perspective. Nonetheless, the absence of heating can have other health implications for low-income communities [45]. These implications are not the same in all places - for example in the Terai, the climate is warmer. Hence, the co-benefit of space heating has a much lower value and can even be undesirable, acting as a driver for MCS.

The four issues discussed above show that the existing body of literature on MCS adoption does not situate MCS against TCP in their broader socio-economic, cultural, and ecological contexts. Highlighting the benefits of MCS, or limiting the comparison of MCS with TCP in terms of pure convenience and health benefits, will not only miss several important interlinkages with livelihoods but will also understate the co-benefits of the accompanying socio-ecological processes [2, 47]. Existing literature on social practice, on the other hand, has explored the gender, health, and capability dimensions of household cooking behaviour $[49,50]$. These issues might not be perceived as important by households themselves, in the same way, that they are by government or other agencies who are promoting MCS. Therefore they may not play a strong part (if any) in household decision making criteria.

Therefore, household energy use behaviour requires a comprehensive understanding of factors within and beyond the household [51]. Household decision making on cooking energy options can be analysed as a socio-technical system, comprising many interlinked factors [52]. Van der Kroon et al. [53] identified three categories of factors that shape cooking energy choices at the household level in rural areas of developing countries:

i. "the country external environment shaping the boundaries within which a society has to function (such as climate, geographic location and history) 
Bharadwaj, Bishal, David Pullar, Long Seng To, and Jon Leary. "Why Firewood? Exploring the CoBenefits, Socio-Ecological Interactions and Indigenous Knowledge Surrounding Cooking Practice in Rural Nepal." Energy Research \& Social Science, https://doi.org/10.1016/j.erss.2021.101932 (accepted manuscript)

ii. the decision context reflecting household external and country internal factors based on the institutional, political and market situation of a specified location (factors include capital market, government policies, consumer markets etc.); and

iii. the household opportunity set representing a group of household internal factors based upon the characteristics and factor endowment of the household."

The framework highlights that it is the interaction between these different categories that ultimately shapes each household's decision. The interaction of these interlinked factors develops place-specific energy needs and TCP is adapted to satisfy these contextual needs [23]. The current literature is thin concerning these advantages. Not knowing how TCP satisfies users' expectations and the benefit it provides in a wide range of socio-ecological contexts could lead to unintended consequences [47]. Each household has its own decisionmaking criteria, which is influenced by their local context. Failure to understand this decision context in full creates a gap between what MCS can deliver and user expectations that will ultimately fail to attract the household to adopt and lead to failed interventions [23, 47, 54].

\subsection{Towards a better strategy for clean cooking in rural communities in Nepal}

TCP is the outcome of a long-term interaction between humans and the socio-ecological systems in which they exist. On one side, the benefits of MCS, such as lower emissions and health benefits, may not be the primary criteria in household decision making [55].

Frequently, too much focus is placed on the technical aspects alone, ignoring social barriers and leading to the failure of the interventions $[50,55]$. While arguing for the benefits of MCS, policymakers should neither ignore the ecological implications nor understate the influence of the social context that produces such behaviour [46, 55-57]. Thus, gaining better insight into the social context can enrich the design and implementation of MCS programmes 
Bharadwaj, Bishal, David Pullar, Long Seng To, and Jon Leary. "Why Firewood? Exploring the CoBenefits, Socio-Ecological Interactions and Indigenous Knowledge Surrounding Cooking Practice in Rural Nepal." Energy Research \& Social Science, https://doi.org/10.1016/j.erss.2021.101932 (accepted manuscript)

[22] and also contribute to a better understanding of how indigenous knowledge can evolve $[2]$.

Households are more likely to evaluate MCS by the co-benefits that are lost/gained, rather than considering it as a direct replacement for TCP. Seen through the lens of the framework presented by Van der Kroon et al.'s household decision-making framework, the rationale behind the decision of many households to choose firewood as their preferred cooking fuel becomes more apparent. This framework suggests that households aim to reduce their vulnerability and risk by optimizing the net benefit from their cooking fuel choice. The framework positions the household opportunity set as the building block of this livelihood strategy. However, this is framed by both the decision context, resulting from the external political, institutional and market environment, as well as the country external environment. When external agencies such as GoN or private sector actors promote a specific MCS, to replace or alter one aspect of this complex system, the whole system is likely to be affected, resulting in unintended consequences or low levels of uptake.

When households compare MCS with TCP, these sacrifices, risks and opportunities are carefully evaluated as benefits from TCP or costs of MCS. Risks include operational risks (such as LPG explosion, shortage or supply-side uncertainties, and lack of technical support such as maintenance [58]) and the fear of losing indigenous knowledge. The benefits also come in many different forms, such as employment opportunities from firewood collection; and social value, such as the psychological attachment to particular rituals. Therefore, we argue that identifying the co-benefits of TCP and the risks associated with transiting to MCS are a key pathway to operationalise the household opportunity set. 
Bharadwaj, Bishal, David Pullar, Long Seng To, and Jon Leary. "Why Firewood? Exploring the CoBenefits, Socio-Ecological Interactions and Indigenous Knowledge Surrounding Cooking Practice in Rural Nepal." Energy Research \& Social Science, https://doi.org/10.1016/j.erss.2021.101932 (accepted manuscript)

Sacrifices, risks and opportunities are of course contextual: whilst some may be nationally applicable, others are localised to specific regions in Nepal. For instance, the cobenefits of TCP in mountain ecologies are likely to differ in some aspects to those in humid tropical areas. Van der Kroon's framework facilitates the comparison of household decision making in different places based upon the features of the decision context and external environment in each place.

To complement the existing literature, in this paper, we use the framework presented by Van der Kroon et al and argue in favour of TCP to provide insight on the underlying cobenefits and draw attention to the necessity of including the impact of MCS uptake on socioecological and other valuable services provided by TCP. This argument is designed to contribute to the existing literature on MCS in three ways:

1. understanding households' motivations to continue TCP;

2. understanding the implications of pushing MCS in techno-centric programmes; and

3. developing context-specific solutions to facilitate sustainable transitions that better meet household needs.

The paper is structured as follows: section 2 lays out the methodology employed; section 3 presents and discusses the results, highlighting the often overlooked co-benefits of TCP and the risks associated with techno-centric drives toward the adoption of MCS; and finally in section 4 , we present strategies that can facilitate a more sustainable and culturally-informed transition to clean cooking in Nepal.

\section{Method}

Household cooking practices and energy use more broadly are complex processes linked with other livelihood strategies and socio-ecological systems. Given these 
Bharadwaj, Bishal, David Pullar, Long Seng To, and Jon Leary. "Why Firewood? Exploring the CoBenefits, Socio-Ecological Interactions and Indigenous Knowledge Surrounding Cooking Practice in Rural Nepal." Energy Research \& Social Science, https://doi.org/10.1016/j.erss.2021.101932 (accepted manuscript)

complexities, we aim to gather new insights by considering the social context as a whole, instead of focusing on just one part of the system (e.g. the effect of income on cooking fuel choice) $[60,61]$. Insight can be gained by exploring the context in which a particular behaviour evolves and develops a synergistic relationship with household livelihoods. In such a situation, case studies can be particularly useful, as what is seen by outsiders might differ from what is inside the household; an aspect that ethnographic case study research can explore [62]. However, in diverse societies where practices vary by ethnic group, geography, ecology and socio-economic status, many case studies would be required to explore the wide range of practices. Thus, in this paper, we employ a mixed-methods approach, comprising of field observations, a literature review and a survey (Figure 1). These techniques offer an overview of many different cases by drawing from the extensive experience of many studies and respondents of the survey.

Figure 1 - Data collection and verification process used in this study.
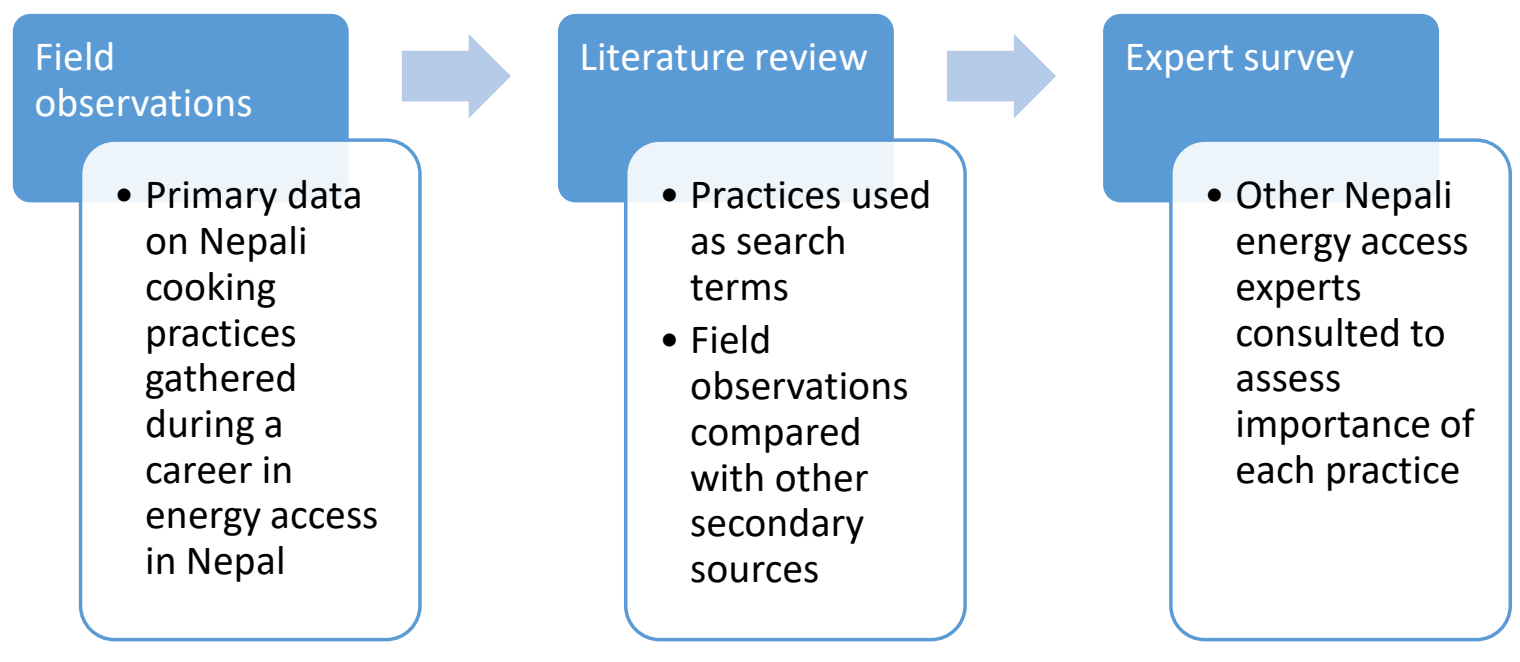

The following themes emerging from the field observations and literature review, which were used to structure the data verification during the expert survey: 
Bharadwaj, Bishal, David Pullar, Long Seng To, and Jon Leary. "Why Firewood? Exploring the CoBenefits, Socio-Ecological Interactions and Indigenous Knowledge Surrounding Cooking Practice in Rural Nepal." Energy Research \& Social Science, https://doi.org/10.1016/j.erss.2021.101932 (accepted manuscript)

- User-centred comparison of MCS to firewood

- Co-benefits - TCP-linked services

- Belief and perceptions

- Co-benefits - Use and associated activities

- Indigenous knowledge

- Socio-ecological interactions

\subsection{Field observations}

The research process for this paper began with field observations by the lead author throughout a career in energy access in Nepal spanning several years. This included:

- $\quad$ surveys, such as the study of community and forest interdependence (using a household survey in Kanchanjunga conservation areas during 2005 and a household survey to explore the diverse use of bamboo in Ilam district during 2006);

- field visits to more than 30 districts (such as a field visit to understand clean energy access, its driver and barrier and use in Okhaldung and Solukhumbu in 2019);

- a decade long professional experience within GoN in the various role and as an officer in the environmental management section of the Ministry of Local Development (which also facilitates local Government in renewable energy technology promotion); and

- personal experiences of cooking with firewood, biogas, kerosene, LPG and electricity at home as a Nepali.

The key limitation of field observations is the inherent bias towards the personal experiences of the author. To combat this bias, we supported these observations with a literature review and survey to understand whether the practices and interlinkages identified were also deemed 
Bharadwaj, Bishal, David Pullar, Long Seng To, and Jon Leary. "Why Firewood? Exploring the CoBenefits, Socio-Ecological Interactions and Indigenous Knowledge Surrounding Cooking Practice in Rural Nepal." Energy Research \& Social Science, https://doi.org/10.1016/j.erss.2021.101932 (accepted manuscript)

important by others. The observations were first divided into practices (see Table A3 in Appendix). Each practice was then converted into a set of search terms for the literature review to identify studies that have already explored these particular topics. Each practice also featured as a statement in the survey, allowing respondents to express how important they thought each practice is and how widespread it is across the country. Finally, both the supporting and conflicting evidence from these two supplementary methods was discussed alongside the field observations to offer a more balanced perspective.

\subsection{Literature review}

This study aims to offer more holistic insight into the social context of cooking practices in the rural areas of the Himalaya by comparing the practices that accompany firewood use and their synergies with livelihoods and the broader socio-ecological systems. The breadth of this scope poses a challenge to a review of the literature in two main ways. First, the practices are often unique to a particular culture or location, making the literature patchy in some areas $[63,64]$. Secondly, there is a geographical bias in energy studies that results in very little literature on the social practices of cooking in developing countries as a whole and even more so to the specific practices observed in different regions of Nepal [65]. To deal with these challenges, we used a simplified form of subject-wide evidence synthesis [64]. This synthesis used firewood services, e.g. pest management or insect deterrent, to look for evidence from Nepal in peer-reviewed journals, as well as grey literature (see Table A3 in the appendix). The synthesis process is particularly important to locate findings on cooking practices and its linkage with livelihoods in the mountains of Nepal within the sparse evidence base [63]. Newspaper articles and reports were also included, as they can contain valuable insights into much-localised beliefs and practices in Nepal that would otherwise remain hidden. 
Bharadwaj, Bishal, David Pullar, Long Seng To, and Jon Leary. "Why Firewood? Exploring the CoBenefits, Socio-Ecological Interactions and Indigenous Knowledge Surrounding Cooking Practice in Rural Nepal." Energy Research \& Social Science, https://doi.org/10.1016/i.erss.2021.101932 (accepted manuscript)

\subsection{Survey}

Finally, we used a questionnaire to survey 40 respondents, who have extensive knowledge of local practices, energy, environment and local development in Nepal. The survey was administered using an online tool called Checkbox ${ }^{\circledR}$ from May and June of 2020. Table-A1 shows that participants were drawn from a variety of areas of engagement (local and national government, civil society, academia, project implementation and field research) to reduce bias towards one particular perspective. Our survey represented 24 districts out of 77 , and all 7 provinces in Nepal. 12 respondents were female; however, we did not collect information on caste and age of the participant. Although, opinion can provide valuable information for exploratory research, it also easy for the respondents to be biased [63]. To reduce the bias, we use a set of strategies such as randomising the order of the questions and the options in each question. Participants were allowed to save, edit, reset and revise their response to improve the quality of the responses to open-ended questions in particular.

\section{Why firewood: Results and discussion}

This section explores the services supplied by TCP, either directly or indirectly via rural livelihoods, by presenting the field observations alongside the results of the literature review and survey. It starts by comparing firewood with other cooking options, highlighting the scores attributed to each by survey respondents. The ranking is then followed by a description of each of the services offered by TCP and a discussion on the importance attributed to each service by survey participants.

\subsection{Comparison of TCP and MCS using a social context lens}

Identification of the root causes behind the sluggish transition to clean cooking has to begin with a comparison of MCS to TCP based on social context rather than technological specification. A long list of the technological advances of MCS can neither sufficiently 
Bharadwaj, Bishal, David Pullar, Long Seng To, and Jon Leary. "Why Firewood? Exploring the CoBenefits, Socio-Ecological Interactions and Indigenous Knowledge Surrounding Cooking Practice in Rural Nepal." Energy Research \& Social Science, https://doi.org/10.1016/i.erss.2021.101932 (accepted manuscript)

explain the constraints, nor justify its superiority over TCP. Households frequently favour the broad range of co-benefits, ease of maintenance and familiarity over marginally superior technical specifications of MCS.

Table 2 presents the average rank for TCP and MCS in the rural context of Nepal attributed to each criterion by survey respondents. Firewood scored poorly in health and safety, presumably due to indoor air pollution, the risks of burns and fire catching the building. In contrast, eCooking was ranked top in health and safety. Biogas was ranked as the best option for co-benefits and socio-ecological interaction. Biogas is not only clean in the kitchen, but also connects with cattle ownership and manure production, and is environmentally benign. LPG ranked lowest on operation cost, due to its ongoing fuel purchasing requirements, and was not identified as the best option in any aspect. Kerosene is ranked lowest in most options. All MCS were ranked lowest in one aspect: eCooking in maintenance, biogas in installation cost and LPG in operation cost.

We see in Table-1 that firewood ranked highest in most of the criteria and did not rank lowest in any aspect. Firewood is ranked best for operation cost, installation cost, accessibility, operational flexibility, ease of maintenance and suitability for cultural practices. Operational flexibility and suitability for cultural practices are important MCS adoption criteria [23], yet the respondent ranked firewood higher. The ability to accommodate different pot size and shapes and the ability to quickly build temporary stoves enable the household to satisfy their diverse needs, including multitasking and outside cooking [66], which is likely to explain why the respondent ranked firewood highest for operational flexibility. Most imported MCS is available in fixed structures that force households to compromise cultural and demographic needs $[23,42,67]$. Firewood is also ranked highest by the respondents for 
Bharadwaj, Bishal, David Pullar, Long Seng To, and Jon Leary. "Why Firewood? Exploring the CoBenefits, Socio-Ecological Interactions and Indigenous Knowledge Surrounding Cooking Practice in Rural Nepal." Energy Research \& Social Science, https://doi.org/10.1016/j.erss.2021.101932 (accepted manuscript)

ease of maintenance, another influential criterion for adoption and sustained use [68]. Much imported technology is hard to maintain locally in rural areas, and substantial time and cost may be needed to take it to an urban area for maintenance. In contrast, indigenous knowledge and skills relating to the repair and modification of traditional cookstoves are widespread [29].

Table-1: Comparing Modern Cooking Solutions (MSC) to firewood in the context of rural Nepal.

\begin{tabular}{lrrrrrr}
\hline Criteria & Firewood & LPG & \multicolumn{1}{c}{ Biogas } & eCooking & Kerosene \\
\hline Operation Cost & 1.74 & 3.90 & 2.51 & 3.10 & 3.74 \\
Installation Cost & 1.46 & 3.67 & 3.90 & 3.18 & 2.79 \\
Accessibility & 1.21 & 3.41 & 2.97 & 3.67 & 3.74 \\
Health and Safety & 3.92 & 2.90 & 2.08 & 1.85 & 4.26 \\
Operational Flexibility & 1.56 & 3.08 & 3.15 & 3.74 & 3.46 \\
Suitability for cultural practices & 1.18 & 2.64 & 3.23 & 4.33 & 3.62 \\
Co-benefits & 2.36 & 3.46 & 1.54 & 3.18 & 4.46 \\
Easy to maintain & 1.51 & 3.33 & 3.23 & 3.62 & 3.31 \\
Socio-ecological interaction & 2.03 & 3.69 & 1.72 & 3.38 & 4.18 \\
\hline
\end{tabular}

Note: Scores indicate the average (mean) of the rank assigned to each cooking technology for each criterion, with 1-the highest and 5-the lowest. Green highlights the highest and Red highlights the lowest-scoring option.

\subsection{Underlying drivers of firewood use}

Table-2 presents the mean value of survey responses for the prevalence of firewood-related services and its importance to households. In Table A2, we summarised the 23 services/uses connected with firewood reported by our participants. Many of these services were also discussed in the literature, reports and online news portals, the most relevant of which are 
Bharadwaj, Bishal, David Pullar, Long Seng To, and Jon Leary. "Why Firewood? Exploring the CoBenefits, Socio-Ecological Interactions and Indigenous Knowledge Surrounding Cooking Practice in Rural Nepal." Energy Research \& Social Science, https://doi.org/10.1016/i.erss.2021.101932 (accepted manuscript)

mentioned in the text below and summarised in Table A3 in the appendix. These valuable services equate to sacrifices a household must make when replacing TCP with MCS, i.e. additional costs of adopting MCS.

Firstly, firewood is readily available in rural hills of Nepal. Increasing forest cover and decreasing population density in these areas have increased the per capita forest areas [69]. Where forests are far away, households practice agroforestry to supply firewood [48].

Plantations of fast-growing tree species like Alnus Nepalis [70] also supply firewood.

Deadwood and stems from the rejuvenation of agroforestry [71]; leftovers from cattle fodder; used bamboo; agricultural waste such as broom grass and jute; and seasonal thinning of trees also supplies a huge amount of solid fuel (Table 2, row(4)). Appendix Table-1 presents the use of firewood and its products, as reported by the respondents in the survey.

Table-2 Extent and importance of TCP-linked services to rural livelihood

\begin{tabular}{|c|c|c|c|}
\hline & & 1 & 2 \\
\hline Row & Firewood service & $\begin{array}{l}\text { Extent of } \\
\text { practice }\end{array}$ & $\begin{array}{l}\text { Importance to } \\
\text { livelihood }\end{array}$ \\
\hline 1 & $\begin{array}{l}\text { Households plant trees in their homestead to supply cattle } \\
\text { fodder, fruits, and firewood }\end{array}$ & 1.21 & 2.59 \\
\hline 2 & $\begin{array}{l}\text { Use of firewood motivates households to join community } \\
\text { forest user groups }\end{array}$ & 1.33 & 2.44 \\
\hline 3 & $\begin{array}{l}\text { Households use different cookstoves to prepare food and } \\
\text { cattle feed }\end{array}$ & 1.56 & 2.26 \\
\hline 4 & $\begin{array}{l}\text { Households use waste such as used bamboo and twig (Jhikra) } \\
\text { around the homestead as fuelwood, contributing to waste } \\
\text { management and sanitation }\end{array}$ & 1.33 & 2.28 \\
\hline 5 & Heating around the fire is a recreational activity & 1.97 & 1.84 \\
\hline 6 & Firewood ash is used for washing dishes and hands & 1.63 & 2.03 \\
\hline 7 & $\begin{array}{l}\text { Firewood ash is used as a pesticide to protect crops and } \\
\text { grains }\end{array}$ & 1.55 & 2.32 \\
\hline 8 & Firewood smoke is used to dry seeds (such as garlic) & 1.94 & 1.87 \\
\hline 9 & Firewood ash is used in several traditional medicines & 2.27 & 1.79 \\
\hline 10 & Firewood is used for space heating in cold areas of Nepal & 1.42 & 2.58 \\
\hline
\end{tabular}


Bharadwaj, Bishal, David Pullar, Long Seng To, and Jon Leary. "Why Firewood? Exploring the CoBenefits, Socio-Ecological Interactions and Indigenous Knowledge Surrounding Cooking Practice in Rural Nepal." Energy Research \& Social Science, https://doi.org/10.1016/j.erss.2021.101932 (accepted manuscript)

11 The family gather together around a wood fire, heat themselves, exchange thoughts and plan activities

12 People collect firewood in groups and interact with each other

13 People combine firewood collection with other activities, such as cattle grazing, vegetable collection

Note: Values are means of all responses. For col (1) $1=$ common (green), $2=$ regional (yellow), $3=$ local (orange) and $4=$ not practiced (red). For column(2) $1=$ not important (red), $2=$ important (yellow) and $3=$ very important (green).

Firewood is not only widely available but also free to collect in many rural hills of Nepal [28]. This free collection avoids any monetary fuel cost and makes firewood inherently more cost-effective than other solutions $[19,34,66]$. Firewood collected for free can also be sold to those with an income who prefer not to collect themselves. The collection of firewood, therefore, provides self-employment opportunities [72], which is backed up by the respondents to our survey (see Table 3 (row(11) later in this section).

When collecting firewood, a household is also contributing to its socio-ecological system (Table 2, row(1,2 \&13)). For example, households often plant fast-growing fodder trees such as Mulberry and Mountain Ebony to increase farm income and generate fuelwood [73]. Firewood collection is carried out together with searching for wild vegetables such as Niguro (Dryopteris cochleata) and mushrooms and also while grazing animals [74, 75]. These wild food sources make up a valuable source of nutrition for poor households [76].

TCP also produces useful by-products, which otherwise need to be purchased (Table 2, row (5-10) \& Table-A2). Firewood produces ash, which is used to protect seeds and grains from pests, as a detergent to wash utensils and for handwashing (especially in remote areas where shops are far away). Rural households also use solid fuel ash to protect plants and stored food from pests (Table 2, row(7)) [77]. The survey results strongly support the use of firewood by-products, except its use as traditional medicine, which is only supported by some 
Bharadwaj, Bishal, David Pullar, Long Seng To, and Jon Leary. "Why Firewood? Exploring the CoBenefits, Socio-Ecological Interactions and Indigenous Knowledge Surrounding Cooking Practice in Rural Nepal." Energy Research \& Social Science, https://doi.org/10.1016/j.erss.2021.101932 (accepted manuscript)

respondents (Table 2, row(9)). This may be because the use of specific medicines is regional, so some respondents may have been unaware of its use in areas they are not familiar with.

TCP can also offer a waste management strategy in rural areas (Table 2, row(4)). Agriculture and forests produce a massive amount of waste material in rural households. This waste material, such as leftover branches from cattle fodder and twigs from thinning and pruning of orchards, used bamboo/wood, dead trees, crops residues (e.g. broom grass and tea plant), construction materials (e.g. timber frames or straw roofing from demolished buildings) is regularly used as firewood in rural Nepal (See Photo-2, middle). Given the absence of waste management facilities and the fact that some of these waste streams are very slow to compost, households prevent the need to find other means of disposal by using it as solid fuel.

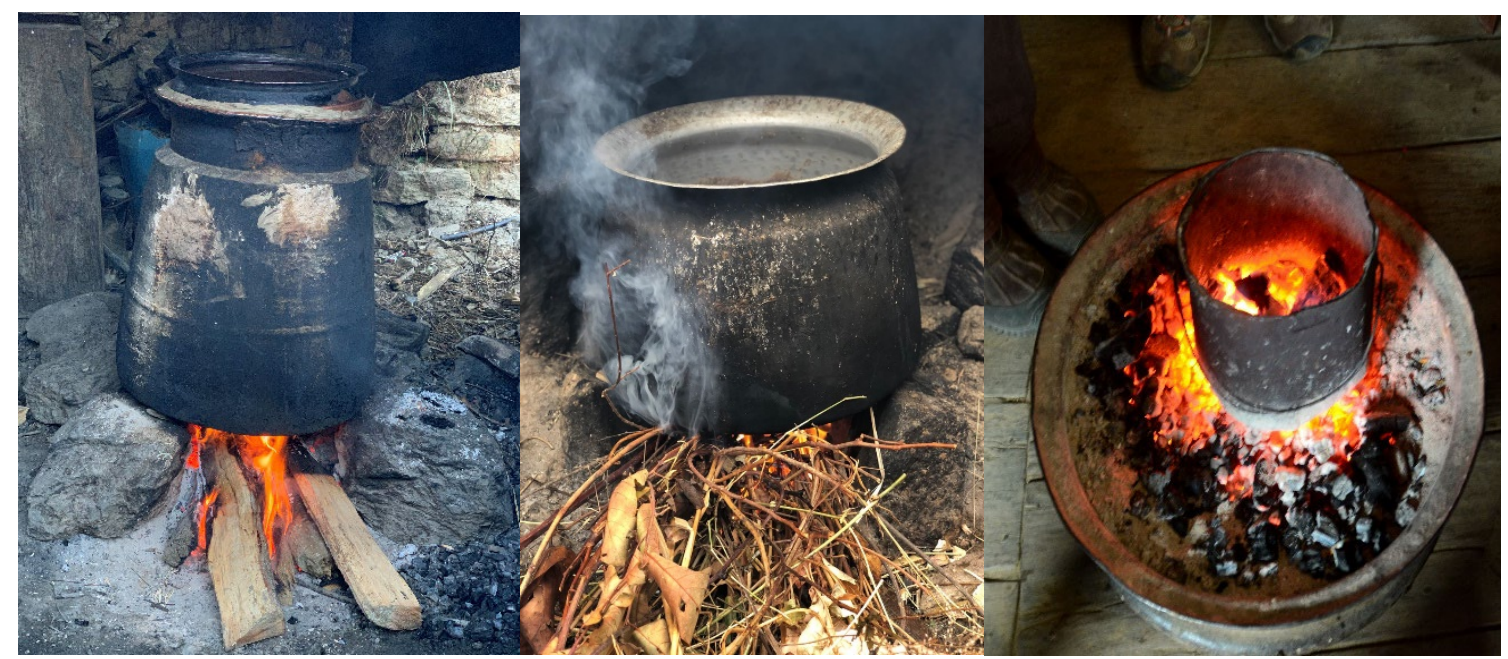

Photo-2: Firewood used to prepare alcohol (Left); fodder leftover used to prepare cattle feed (Middle) and firewood charcoal used for heating (Right). Photo Credit from Left to Right: Ramila Bhandari, Mukti Subedi and Damber Bista.

Nepali foods have evolved together with TCP. Households know how to create the required heat intensity from a firewood stove for each food item [72]. For example, Selroti is a doughnut-shaped item made from rice flour that is considered tastiest when prepared in hard-wood, as it burns hotter. Nepal is inhabited by people from diverse cultural 
Bharadwaj, Bishal, David Pullar, Long Seng To, and Jon Leary. "Why Firewood? Exploring the CoBenefits, Socio-Ecological Interactions and Indigenous Knowledge Surrounding Cooking Practice in Rural Nepal." Energy Research \& Social Science, https://doi.org/10.1016/j.erss.2021.101932 (accepted manuscript)

backgrounds, each with culturally-distinct cuisines with specific accompanying cooking practices. These include cooking processes, beliefs, food preferences and most desirable varieties of solid-fuel (a behaviour also observed in the Himalayan region in India [42]). For example, Nepalese enjoy Poleko items, a common practice, prepared by placing raw ingredients, such as meat, potato, and corn, directly onto hot charcoal [78]. These are everyday items which can easily be prepared in a traditional cookstove. Yet, it is very difficult, or impossible, to do so in MCS because they do not have a chimney-like shape to funnel the heat or hot charcoal to roast or heat (Photo 2: Right).

Nepal is rich in cultural diversity, much of which is based upon localised variations of TCP (See Table A4). Each cultural group has specific pots and utensils to cook food. For example, traditional pot to distil alcohol (see Photo-2 Left), Tai - a thick iron pan to prepare Selroti, and Hadi- a mud container used to make a popcorn[78]. These pots have a different size and shape that often cannot fit onto the standard sized MCS burner.

TCP is a symbol of cultural identity that has a social value attached to it. Even in urban areas, many households build traditional cookstoves to use during special occasions. The use of multiple cookstoves in TCP is advantageous in many cultural settings. For example, when a household has a mix of vegetarian and non-vegetarian members and in households where elder members of the family resist sharing a kitchen with other members due to clan deity beliefs or other reasons, people use a cookstove located outside the house. People tend to store fuel in a separate bamboo shed known as Katero so that it can be used throughout the year and during emergencies. One respondent mentioned that the size of the firewood stack symbolises the social status of the household. This stack assures energy supply during the rainy season. 
Bharadwaj, Bishal, David Pullar, Long Seng To, and Jon Leary. "Why Firewood? Exploring the CoBenefits, Socio-Ecological Interactions and Indigenous Knowledge Surrounding Cooking Practice in Rural Nepal." Energy Research \& Social Science, https://doi.org/10.1016/j.erss.2021.101932 (accepted manuscript)

People use different cookstoves in different seasons depending on the ecology of their village. For instance, in hot and humid areas, households cook indoors during the monsoon season and outdoors during winter [29]. Cookstoves in tropical areas are usually slim and open flamed, focusing as much of the heat onto the pot as possible. Whereas in cold climates, they are typically much bigger structures, designed for space heating as well as cooking. Cooked foods are often placed in an additional part of traditional cookstoves to keep warm for some hours, allowing flexibility between cooking and eating times. In cold areas, warm drinks are essential. After eating, households often place a stove-top kettle (or teapot) in the Bhungro or the cookstove itself for later use to avoid having to light traditional stoves again. This warming of food and water is an essential feature of cooking practice in high hills and mountainous areas where households have a greater need for warm water but lack modern water heating systems in their home.

Living without space heating is almost impossible in most of the high hill and mountainous areas of Nepal. A sophisticated heating system is near impossible due to a lack of other essential energy services. In this situation, the households use TCP as a source of heat to keep themselves warm, heat water and for space heating [79]. Realising the critical need for these additional heating services, the Government promoted metallic improved cookstoves in high elevation areas, as they deliberately radiate heat to the surroundings [80].

Transhumance, or seasonal movement of livestock between fixed summer and winter pastures, is common in high altitude areas [81]. MCS is neither feasible nor available in such areas; TCP, which is easily adaptable in these circumstances, not only provides cooking services but also offers protection from cold weather and wild animals. However, restriction 
Bharadwaj, Bishal, David Pullar, Long Seng To, and Jon Leary. "Why Firewood? Exploring the CoBenefits, Socio-Ecological Interactions and Indigenous Knowledge Surrounding Cooking Practice in Rural Nepal." Energy Research \& Social Science, https://doi.org/10.1016/i.erss.2021.101932 (accepted manuscript)

in collecting fuelwood contributes to change in transhumance practice in high hills of Nepal [82].

Another important service identified and supported by respondents is drying of foods and seeds for preservation (Table-2 row $(7 \& 8)$ ) so that they can be used in another season, or sold in markets that may be far away. In rural areas, the storage of food and seeds for offseason use is challenging. Households widely use smoke and heat from TCP to dry and protect these products. There is often a particular place, usually just above the cookstove, to store and dry food and seeds. Meat is often smoked and stored for future use.

Besides food and seeds, preservation is also vital for the property itself. Houses are often built using unprocessed wood, thatches, and bamboo that are vulnerable to termites. There is a strong belief that smoke deters termites and preserves the house through the processes of drying and fumigation $[66,79]$. Houses are commonly surrounded by forest and bushes with cattle sheds nearby in rural Nepal. The evening light attracts insects and mosquitoes into the house. However, many households believe the TCP smoke deters these insects from coming inside the house.

Table 3 presents the mean values for the level of agreement with each of the perceptions and benefits associated with firewood from the survey. Participants agreed with most of the proposed statements derived from the field observations, although the level of agreement varies. The only exception is that they disagreed with the statement on the repulsive smell of LPG (mean value 3.12, Table 3 row(4)). Even though most of the participants were using MCS in their own homes, they strongly agreed that there is a perception that food cooked in firewood tastes best (mean value 1.71, Table 3 row(6)), that firewood is best for some specific cultural foods (mean value 1.53, Table 3 row(14)). This 
Bharadwaj, Bishal, David Pullar, Long Seng To, and Jon Leary. "Why Firewood? Exploring the CoBenefits, Socio-Ecological Interactions and Indigenous Knowledge Surrounding Cooking Practice in Rural Nepal." Energy Research \& Social Science, https://doi.org/10.1016/j.erss.2021.101932 (accepted manuscript)

association with the flavour and taste [83]; cultural practices [42]; social taboos [57]; and social norms [50] strongly influences household decision making.

Table 3: Level of agreement on perceptions and benefits associated with firewood.

\begin{tabular}{rlr}
\hline \multicolumn{1}{c}{ Row } & \multicolumn{1}{c}{ Statement } & Mean \\
\hline Panel A: Belief and perception & 2.03 \\
\hline 1 & Overall, firewood is the most resilient cooking fuel in Nepal & 1.68 \\
2 & Firewood smoke causes respiratory health problems & 2.28 \\
3 & People ignore the effect of firewood smoke on their health & 3.12 \\
4 & LPG smells terrible, and many people do not like it & 1.92 \\
5 & There is the widespread perception that smoke deters insects entering the house & \\
& There is the widespread perception that food cooked on firewood is tastier than cooked in \\
6 & other cookstoves like LPG & 1.71 \\
& There is the widespread perception that smoke from firewood increases the strength of \\
7 & wood in the house & 1.84 \\
\hline Panel B: Use and associated activities & 2.41 \\
\hline 8 & Using firewood will clean the waste around your environment, such as twigs from trees \\
9 & Households use firewood to heat the house & 1.97 \\
10 & While collecting firewood, people also do other activities, such as collect vegetables \\
11 & Firewood collection is an opportunity for the household to work to avoid the fuel cost \\
12 & Collecting firewood helps remove dead trees and allows a new tree to grow & 2.05 \\
13 & Collecting firewood will reduce forest fires & 2.03 \\
& Firewood is best suitable to prepare cultural foods such as Selroti and roasted corn (Poleko \\
14 & Makai in Nepali); and liquor such as alcohol & 1.87 \\
\hline
\end{tabular}

Note: Values are means of all responses. Strongly Agree $=1$, Agree $=2$, Neutral $=3$, Disagree $=4$, Disagree $=5$.

Similarly, the participants generally agree that firewood is the most resilient fuel in Nepal (mean 2.03, Table 3 row(1)), but a source of respiratory health problems (mean value 3.12, Table 3 row(2)). Participants strongly agreed that firewood deters insects (mean value 1.92, Table 3 row(5)), increases wood strength (mean value 1.84, Table 3 row(7)). That firewood collection is an opportunity to reduce the cost of fuel (mean value 2.03, Table 3 row(11)). The inheritance of TCP from previous generations makes this indigenous knowledge an integral part of Nepalese culture and social norms. These social norms can often be more influential than the health risks associated with TCP [57]. 
Bharadwaj, Bishal, David Pullar, Long Seng To, and Jon Leary. "Why Firewood? Exploring the CoBenefits, Socio-Ecological Interactions and Indigenous Knowledge Surrounding Cooking Practice in Rural Nepal." Energy Research \& Social Science, https://doi.org/10.1016/j.erss.2021.101932 (accepted manuscript)

To summarise, TCP has extensive linkages with rural livelihoods, not only by supplying essential household services but also through maintaining socio-ecological systems. Comparing TCP against MCS provides a more holistic understanding of why the practice of cooking with firewood continues [84].

\subsection{Risks of MCS adoption}

This section considers the risks associated with techno-centric drives toward the adoption of MCS by discussing them with reference to the indigenous knowledge and socio-ecological interactions associated with TCP. Communities extract and sustain benefit from nature through several channels, such as indigenous knowledge and policy-driven practices $[2,85$, 86]. People have been cooking with firewood for thousands of years, during which time they have accumulated the knowledge required to carry out this practice effectively [1].

Households remove dead wood and unnecessary plants from the forest [72]. While doing so, they create space for new trees, reducing the fuel load to prevent the occurrence of forest fires. In recent decades, out-migration from remote rural areas has left many hectares of farmland fallow. Increasing forest cover encroaches these fallow farmlands. In this situation, households cut firewood from this encroaching forest - protecting farmland and preventing pests and wild animals entering into the village [87]. To put this in context, an excerpt from a Nepali Newspaper can be helpful: "leopard attacks are becoming increasingly common with the spread of community forests, and out-migration has allowed vegetation to cover fallow farmland." [88]

Table-4 presents the association of TCP with socio-ecological interactions and indigenous knowledge. TCP is deeply rooted in the socio-economic and socio-ecological context of rural communities [43]. Although the strengths of MCS are widely discussed in the 
Bharadwaj, Bishal, David Pullar, Long Seng To, and Jon Leary. "Why Firewood? Exploring the CoBenefits, Socio-Ecological Interactions and Indigenous Knowledge Surrounding Cooking Practice in Rural Nepal." Energy Research \& Social Science, https://doi.org/10.1016/i.erss.2021.101932 (accepted manuscript)

literature, the impact of replacing TCP by MCS on indigenous knowledge and socioecological systems is thin $[2,42]$.

Table 4: Indigenous knowledge and socio-ecological interactions

\begin{tabular}{|c|c|c|}
\hline Row & Statement & Mean \\
\hline \multicolumn{3}{|c|}{ Panel A: Risk of indigenous knowledge } \\
\hline 1 & Use modern stoves like LPG reduce the cooking of traditional cuisines & 2.82 \\
\hline 2 & $\begin{array}{l}\text { Traditional food practices such as Sukuti and Poleko-aalu are important to socio-culture } \\
\text { of Nepalese household }\end{array}$ & 2.26 \\
\hline 3 & $\begin{array}{l}\text { Firewood and subsistence farming have a synergistic relationship. When a household } \\
\text { moves away from TCP, it will affect their ability to continue their livelihood strategies }\end{array}$ & 2.66 \\
\hline 4 & $\begin{array}{l}\text { If a household does not need firewood, their participation in community forests will } \\
\text { decrease }\end{array}$ & 2.37 \\
\hline 5 & The use of modern cooking has eroded the skills of cooking traditional cuisines & 2.59 \\
\hline 6 & $\begin{array}{l}\text { Moving away from firewood cooking will reduce the younger generation's attachment } \\
\text { with forest, farm and ecology }\end{array}$ & 2.46 \\
\hline 7 & $\begin{array}{l}\text { Moving away from firewood will reduce the traditional knowledge of people and nature's } \\
\text { sustainable interaction (for example people protect the forest because it gives firewood; } \\
\text { they protect small saplings to ensure future firewood supply) }\end{array}$ & 2.23 \\
\hline 8 & $\begin{array}{l}\text { The use of modern cooking solutions (such as LPG) will contribute to loss of traditional } \\
\text { pots such as Hadi and cooking practices such as roasted potato or corn? }\end{array}$ & 2.03 \\
\hline \multicolumn{3}{|c|}{ Panel B Socio-ecological interactions } \\
\hline 9 & Using firewood motivates planting trees in the homestead & 2.38 \\
\hline 10 & Using firewood increases the participation in community forest user group & 2.11 \\
\hline 11 & Firewood is readily available in rural areas of Nepal & 2.23 \\
\hline 12 & Most of the households in remote rural areas collect firewood themselves & 1.46 \\
\hline 13 & $\begin{array}{l}\text { While collecting firewood from the forest, people try to find dead and dried trees as } \\
\text { firewood }\end{array}$ & 1.95 \\
\hline 14 & $\begin{array}{l}\text { Households collect firewood around their farm and homestead so that the risk of wild } \\
\text { animals and pests entering their fields is reduced }\end{array}$ & 2.66 \\
\hline
\end{tabular}

Note: Values are means of all responses. Strongly Agree $=1$, Agree $=2$, Neutral $=3$, Disagree $=4$, Strongly Disagree $=5$.

Adoption of MCS means households have to sacrifice TCP-linked services [23, 66].

These sacrifices could produce unintended consequences by disturbing the socio-ecological system. While pushing MCS, we often forget households have various other needs in addition 
Bharadwaj, Bishal, David Pullar, Long Seng To, and Jon Leary. "Why Firewood? Exploring the CoBenefits, Socio-Ecological Interactions and Indigenous Knowledge Surrounding Cooking Practice in Rural Nepal." Energy Research \& Social Science, https://doi.org/10.1016/j.erss.2021.101932 (accepted manuscript)

to cooking energy. As there is widespread poverty in developing countries, households have to fulfil their pressing needs with only a minimal income (if any at all). The decision to adopt MCS is contextual [56]. Still, incentivising MCS for social, and environmental benefit might force households to compromise other factors, with which they would have been better off, resulting in net private loss [89]. Smith [79] listed the advantages of firewood, intending to inform the development of strategies to replace TCP in households. In addition to this, the cobenefits of and socio-ecological interactions linked to firewood use must be considered, and alternative solutions for these developed in parallel to enable a widespread and sustainable transition to MCS.

Another important set of co-benefits of firewood use is socio-cultural well-being. It is common practice in Nepal to gather together around the heat to share day-to-day experiences and feelings; and discuss household matters (mean value 1.33; Table 4 row(11)). These practices are important to the household and contribute to participatory decision making, planning, and social learning processes. These may be lost with a shift to MCS. Also, when MCS replaces TCP, women and daughters are no longer needed as firewood collectors. This could reduce their self-worth and perceived value within the household, a factor that some have proposed might even contribute towards the motivation for early child marriage [55]. The further potential impact on socio-cultural well-being is likely from this shift in roles and responsibilities within the household.

The loss of extensive Nepali indigenous knowledge associated with TCP is another possibility. Although indigenous knowledge can innovate and adapt to new circumstances, this takes time, and unused practices are likely to be forgotten and disappear. Traditional food is an important part of cultural heritage, however replacing TCP with MCS could trigger the 
Bharadwaj, Bishal, David Pullar, Long Seng To, and Jon Leary. "Why Firewood? Exploring the CoBenefits, Socio-Ecological Interactions and Indigenous Knowledge Surrounding Cooking Practice in Rural Nepal." Energy Research \& Social Science, https://doi.org/10.1016/i.erss.2021.101932 (accepted manuscript)

loss of traditional cuisine, as some foods that are more difficult to cook on MCS may disappear (Table 4 row(2) and Table A2). MCS programmes typically target improved efficiency, environmental benefits and reaching scale as quickly as possible, with much less consideration of cultural diversity and socio-cultural practices.

Although MCS is intended to reduce environmental degradation [37, 90], positive socioecological interactions could be eroded via several channels, such as community forests and agroforestry (Table 4 rows $(4,7 \& 10)$ ). Previous studies have shown that people attempt to conserve, or better manage, forests if they directly benefit from them [91]. As firewood and fodder are important products of community forests in Nepal, reducing the use of these products also means reducing the value of the community forest [92]. Reduced demand for firewood also reduces the value of agroforestry, which can have several implications, including reducing the soil's organic content and reduced fruit supply [71, 73, 93].

The surveyed respondents (Table 4 row $(1,4,5,7,9,10,13 \& 14))$ and the literature both widely agree that TCP positively links households with forests in several ways. For example, collecting firewood provides an opportunity to learn about forest species and their importance. Table A5 summarises firewood use and forest management. Participation in Community Forest User Groups (CFUG) can help to reduce poverty and increase forest density in Nepal [86]. Collection of diseased tree or plant species increases the fuelwood yield; hence the chance of forest fire and disease also reduces. Thinning, as a result of firewood collection, also boosts forest productivity. People contribute to CFUG to obtain a specific personal benefit, usually firewood, fodder, and timber (Table 4 row(10)), however, if MCS is successful in reducing demand for fuelwood, it may also reduce participation in CFUG. 
Bharadwaj, Bishal, David Pullar, Long Seng To, and Jon Leary. "Why Firewood? Exploring the CoBenefits, Socio-Ecological Interactions and Indigenous Knowledge Surrounding Cooking Practice in Rural Nepal." Energy Research \& Social Science, https://doi.org/10.1016/i.erss.2021.101932 (accepted manuscript)

Finally, firewood is the most resilient source of cooking fuel in Nepal. We can consider the case of the cooking fuel crisis due to border blockade after the Nepal earthquake in 2015 (Table A4). LPG was in short supply, so the Government used its machinery to collect and supply firewood in several places to overcome the shortage. As an indigenous resource, firewood was able to substitute for imported LPG and deliver the essential service of cooking during the crisis. Ignoring resilience risks scarcity during disasters and other times of crisis [46].

\section{Conclusions and future work}

This study employed field observations, a survey and a literature review to explore the often overlooked comparative advantages of cooking with firewood to uncover the possible negative implications of the technological push for MCS in Nepal. Our results suggest that $\mathrm{TCP}$, as a livelihood practises in rural areas of Nepal, has several synergistic relations with household welfare, indigenous knowledge and socio-ecological systems. Therefore, a technological push of MCS alone, without other supporting services designed around the cobenefits of firewood use and planning for changes in livelihood structures, risks unintended consequences. Understanding these services and the linkages between TCP and socioecological systems can, therefore, contribute to effective policy development and program design [94].

This study has explored just some of the many implications of transitioning from TCP to MCS. It has shown that when targeting the negative environmental, health and gender equity consequences of TCP, the other vital services it offers (such as space heating and preservation) must also be considered, as social impacts often take a long time to appear and are hard to reverse. There is a substantial knowledge gap in the socio-ecological interactions 
Bharadwaj, Bishal, David Pullar, Long Seng To, and Jon Leary. "Why Firewood? Exploring the CoBenefits, Socio-Ecological Interactions and Indigenous Knowledge Surrounding Cooking Practice in Rural Nepal." Energy Research \& Social Science, https://doi.org/10.1016/j.erss.2021.101932 (accepted manuscript)

and the indigenous knowledge that accompany TCP in diverse socio-cultural settings. This gap limits our understanding of the possible consequences of the technological push for MCS. Uptake of MCS should not necessitate the sacrifice of traditional knowledge, livelihood synergies and linkages into socio-ecological systems. We cannot afford to ignore the impacts simply because we do not understand them well. Looking solely at the benefits of MCS without exploring the broad set of negative social impacts results in a one-sided argument that is likely to result in unintended consequences.

Table 5 presents three strategies that can support the integration of the TCP-linked services into MCS programmes. The first strategy localises MCS to address context-specific needs, the second reduces the negative effects of TCP, whilst the third encourages planning MCS as part of a holistic development intervention.

Table 5: Three strategies for the design of more culturally-informed MCS programmes.

\begin{tabular}{|c|c|c|}
\hline Strategy & Problem & Actions \\
\hline \multirow[t]{2}{*}{$\begin{array}{l}\text { 1: Localise } \\
\text { MCS by } \\
\text { modifying } \\
\text { the design to } \\
\text { suit cultural } \\
\text { and practical } \\
\text { needs }\end{array}$} & $\begin{array}{l}\text { Current MCS are not } \\
\text { aligned with } \\
\text { contextual realities } \\
\text { and cultural needs }\end{array}$ & $\begin{array}{l}\text { - Carry out local consumer research, engaging } \\
\text { local Government and traders to understand the local } \\
\text { context and establish local preferences. } \\
\text { - Develop localised designs for MCS, e.g. to } \\
\text { adapt LPG/biogas for remote areas with specific shape } \\
\text { pots and need for high heat for certain dishes, } \\
\text { develop a portable burner with customised shape/size } \\
\text { and increased maximum power. } \\
\text { admplement practical, low-cost and locally } \\
\text { adaptable modifications to TCPs (see below) and ICS } \\
\text { in contexts where MCS are not yet feasible at all (e.g. } \\
\text { very remote Himalayan villages). }\end{array}$ \\
\hline & $\begin{array}{l}\text { Unreliable MCS } \\
\text { reduce community } \\
\text { resilience, and supply } \\
\text { of MCS in remote } \\
\text { areas is challenging }\end{array}$ & $\begin{array}{l}\text { - Diversify the range of available MCS and } \\
\text { encourage fuel stacking, to avoid households relying } \\
\text { on a single source of energy }[95,96] \text {, to move towards } \\
\text { a completely clean fuel stack, e.g. electricity with LPG. } \\
\text { - Improve supply chains for imported fuels. } \\
\text { - Use locally available energy sources, such as } \\
\text { biogas or eCooking for households connected to } \\
\text { micro-hydro mini-grids. }\end{array}$ \\
\hline
\end{tabular}


Bharadwaj, Bishal, David Pullar, Long Seng To, and Jon Leary. "Why Firewood? Exploring the CoBenefits, Socio-Ecological Interactions and Indigenous Knowledge Surrounding Cooking Practice in Rural Nepal." Energy Research \& Social Science, https://doi.org/10.1016/j.erss.2021.101932 (accepted manuscript)

\begin{tabular}{|c|c|c|}
\hline \multirow[t]{2}{*}{$\begin{array}{l}\text { 2: Improve } \\
\text { TCP to } \\
\text { reduce its } \\
\text { negative } \\
\text { effects, as } \\
\text { fuel stacking } \\
\text { is inevitable }\end{array}$} & $\begin{array}{l}\text { TCP is a source of } \\
\text { indoor air pollution }\end{array}$ & $\begin{array}{l}\text { - Implement practical, low-cost and locally } \\
\text { adaptable modifications to TCPs to reduce the indoor } \\
\text { air pollution risk, e.g. cooking outside or building a } \\
\text { chimney. } \\
\text { - Integrate awareness on health risks of TCP into } \\
\text { MCS programmes. }\end{array}$ \\
\hline & $\begin{array}{l}\text { If woodfuel not } \\
\text { harvested sustainably, } \\
\text { TCP can cause } \\
\text { deforestation and } \\
\text { forest degradation }\end{array}$ & $\begin{array}{l}\text { - Encourage sustainable management of forests, } \\
\text { e.g. via community forest user groups. }\end{array}$ \\
\hline \multirow{3}{*}{$\begin{array}{l}\text { 3: Deliver } \\
\text { MCS as part } \\
\text { of a holistic } \\
\text { array of } \\
\text { development } \\
\text { interventions } \\
\text { designed } \\
\text { around the } \\
\text { co-benefits } \\
\text { of firewood }\end{array}$} & $\begin{array}{l}\text { Programme designers } \\
\text { often overlook TCP co- } \\
\text { benefits }\end{array}$ & $\begin{array}{l}\text { - Identify and evaluate the TCP co-benefits in } \\
\text { each context and design complementary interventions } \\
\text { to deliver the most important services, e.g. smoking of } \\
\text { food can be targeted with solar dryers or in contexts } \\
\text { where organic waste management would otherwise } \\
\text { become problematic, biogas could be promoted. }\end{array}$ \\
\hline & $\begin{array}{l}\text { Lack of economic } \\
\text { opportunities to } \\
\text { generate income to } \\
\text { pay for MCS }\end{array}$ & $\begin{array}{l}\text { - Enable households to diversify livelihoods } \\
\text { beyond forests and agriculture by developing new } \\
\text { economic opportunities to generate a return from } \\
\text { time saved by MCS. }\end{array}$ \\
\hline & $\begin{array}{l}\text { Forcing MCS alone can } \\
\text { jeopardise sustainable } \\
\text { forest management }\end{array}$ & $\begin{array}{l}\text { - Develop alternative services, e.g. if households } \\
\text { stop using firewood, then community forest user } \\
\text { groups can extend forest services to recreation, or } \\
\text { alternative products, such as timber. }\end{array}$ \\
\hline
\end{tabular}

Our study opens up several avenues for future research. The social context in rural areas of Nepal (and many other developing countries) is changing rapidly due to rural development interventions, road expansion, out-migration and remittances. There is a need to gain a deeper understanding of the influence of the changing social context on cooking practices to guide future MCS interventions. Existing understanding of the co-benefits, socio-ecological interactions and indigenous knowledge surrounding TCP is thin but has the potential to support the development of more culturally-informed policy and development programmes in societies where culture forms an integral part of livelihoods. An important area for further research is how these dynamics are experienced differently by different social groups. An intersectional analysis of gender, class and ethnicity, as well as an analysis of the 
Bharadwaj, Bishal, David Pullar, Long Seng To, and Jon Leary. "Why Firewood? Exploring the CoBenefits, Socio-Ecological Interactions and Indigenous Knowledge Surrounding Cooking Practice in Rural Nepal." Energy Research \& Social Science, https://doi.org/10.1016/j.erss.2021.101932 (accepted manuscript)

power dynamics within and beyond the household would enrich our understanding of how cooking practices evolve.

The approach outlined in this paper could be applied to other contexts outside of Nepal and/or to understand why people continue to use other polluting fuels, such as charcoal and kerosene. Our approach could also be used as a tool to plan more holistic interventions in specific contexts within Nepal. Finally, there will also be a need to document case studies of programmes that have successfully integrated the three proposed strategies and delivered a sustainable transition to MCS at scale.

\section{Reference}

[1] S. Diaz, U. Pascual, M. Stenseke, B. Martin-Lopez, R.T. Watson, Z. Molnar, R. Hill, K.M.A. Chan, I.A. Baste, K.A. Brauman, S. Polasky, A. Church, M. Lonsdale, A. Larigauderie, P.W. Leadley, A.P.E. van Oudenhoven, F. van der Plaat, M. Schroter, S. Lavorel, Y. Aumeeruddy-Thomas, E. Bukvareva, K. Davies, S. Demissew, G. Erpul, P. Failler, C.A. Guerra, C.L. Hewitt, H. Keune, S. Lindley, Y. Shirayama, Assessing nature's contributions to people, Science 359(6373) (2018) 270-272.

[2] M.E. Mastrangelo, N. Perez-Harguindeguy, L. Enrico, E. Bennett, S. Lavorel, G.S. Cumming, D. Abeygunawardane, L.D. Amarilla, B. Burkhard, B.N. Egoh, L. Frishkoff, L. Galetto, S. Huber, D.S. Karp, A. Ke, E. Kowaljow, A. Kronenburg-Garcia, B. Locatelli, B. Martin-Lopez, P. Meyfroidt, T.H. Mwampamba, J. Nel, K.A. Nicholas, C. Nicholson, E. Oteros-Rozas, S.J. Rahlao, C. Raudsepp-Hearne, T. Ricketts, U.B. Shrestha, C. Torres, K.J. Winkler, K. Zoeller, Key knowledge gaps to achieve global sustainability goals, Nature Sustainability 2(12) (2019) 1115-1121.

[3] J. Hipolito, B.F. Viana, L.A. Garibaldi, The value of pollinator-friendly practices: Synergies between natural and anthropogenic assets, Basic and Applied Ecology 17(8) (2016) 659-667.

[4] WHO, Burning Opportunity: Clean Household Energy for Health, Sustainable Development, and Wellbeing of Women and Children, World Health Organization, Geneva, Switzerland, 2016.

[5] J. Jetter, Y. Zhao, K.R. Smith, B. Khan, T. Yelverton, P. Decarlo, M.D. Hays, Pollutant emissions and energy efficiency under controlled conditions for household biomass cookstoves and implications for metrics useful in setting international test standards, Environ Sci Technol 46(19) (2012) 10827-34. [6] B. Zhao, H. Zheng, S. Wang, K.R. Smith, X. Lu, K. Aunan, Y. Gu, Y. Wang, D. Ding, J. Xing, X. Fu, X. Yang, K.N. Liou, J. Hao, Change in household fuels dominates the decrease in PM2.5 exposure and premature mortality in China in 2005-2015, Proc Natl Acad Sci U S A 115(49) (2018) 12401-12406. [7] S. Batchelor, E. Brown, N. Scott, J. Leary, Two Birds, One Stone-Reframing Cooking Energy Policies in Africa and Asia, Energies 12(9) (2019) 1591.

[8] NPC, Sustainable Development Goals 2016-2030 National (Preliminary) Report, National Planning Commission, Kathmandu Nepal, 2015, pp. Annex IVg: SDG 7: Ensure access to affordable, reliable, sustainable and modern energy for all.

[9] NPC, Nepal's Sustainable Development Goals: Status and Roadmap: 2016-2030, in: N.P. Commission (Ed.) National Planning Commission, Government of Nepal, Singha Durbar, Kathmandu Nepal, 2017. 
Bharadwaj, Bishal, David Pullar, Long Seng To, and Jon Leary. "Why Firewood? Exploring the CoBenefits, Socio-Ecological Interactions and Indigenous Knowledge Surrounding Cooking Practice in Rural Nepal." Energy Research \& Social Science, https://doi.org/10.1016/j.erss.2021.101932 (accepted manuscript)

[10] NPC, Nepal: Rapid Assessment and Gap Analysis - Sustainable Energy for All, Kathmandu, 2013. [11] CBS, National Population and Housing Census 2011 (National Report) in: C.B.o. Statistics (Ed.) Central Bureau of Statistics Kathmandu, 2012.

[12] CBS, Annual Household Survey of Nepal 2014-2015, in: N. Central Bureau of Statistics (Ed.) Central Bureau of Statistics, Nepal, 2014.

[13] M. Nepal, A. Nepal, K. Grimsrud, Unbelievable but improved cookstoves are not helpful in reducing firewood demand in Nepal, Environment and Development Economics 16(1) (2010) 1-23.

[14] S.L. Pigg, Inventing Social Categories through Place - Social Representations and Development in Nepal, Comparative Studies in Society and History 34(3) (1992) 491-\&.

[15] S. Rai, Biogas: buoyant or bust?, in: D. Gyawali, M. Thompson, M. Verweij (Eds.), Aid, Technology and Development The Lessons from Nepal, Routledge London 2016.

[16] D. Bhattarai, E. Somanathan, M. Nepal, Are renewable energy subsidies in Nepal reaching the poor?, Energy for Sustainable Development 43 (2018) 114-122.

[17] C.T. Thien Thu, P.H. Cuong, L.T. Hang, N.V. Chao, L.X. Anh, N.X. Trach, S.G. Sommer, Manure management practices on biogas and non-biogas pig farms in developing countries - using livestock farms in Vietnam as an example, Journal of Cleaner Production 27 (2012) 64-71.

[18] R. Meeks, K.R.E. Sims, H. Thompson, Waste Not: Can Household Biogas Deliver Sustainable Development?, Environmental and Resource Economics 72(3) (2018) 763-794.

[19] M. Jeuland, J.S.T. Soo, D. Shindell, The need for policies to reduce the costs of cleaner cooking in low income settings: Implications from systematic analysis of costs and benefits, Energy Policy 121 (2018) 275-285.

[20] A.J. Nightingale, H.R. Ojha, Rethinking Power and Authority: Symbolic Violence and Subjectivity in Nepal's Terai Forests, Development and Change 44(1) (2013) 29-51.

[21] R.L. Bryant, Power, knowledge and political ecology in the third world: a review, Progress in Physical Geography 22(1) (1998) 79-94.

[22] S.K. Pattanayak, M. Jeuland, J.J. Lewis, F. Usmani, N. Brooks, V. Bhojvaid, A. Kar, L. Lipinski, L. Morrison, O. Patange, N. Ramanathan, I.H. Rehman, R. Thadani, M. Vora, V. Ramanathan, Experimental evidence on promotion of electric and improved biomass cookstoves, Proc Natl Acad Sci U S A 116(27) (2019) 13282-13287.

[23] M. Catalan-Vazquez, R. Fernandez-Plata, D. Martinez-Briseno, B. Pelcastre-Villafuerte, H. RiojasRodriguez, L. Suarez-Gonzalez, R. Perez-Padilla, A. Schilmann, Factors that enable or limit the sustained use of improved firewood cookstoves: Qualitative findings eight years after an intervention in rural Mexico, PLoS One 13(2) (2018) e0193238.

[24] B.P. Sharma, Household Fuel Transition and Determinants of Firewood Demand in Nepal, Economic Journal of Development Issues 25 \& 26(1-2) (2018) 83-95.

[25] N.L. Lam, B. Upadhyay, S. Maharjan, K. Jagoe, C.L. Weyant, R. Thompson, S. Uprety, M.A. Johnson, T.C. Bond, Seasonal fuel consumption, stoves, and end-uses in rural households of the farwestern development region of Nepal, Environmental Research Letters 12(12) (2017) 125011.

[26] K. Kapri, S. Ghimire, Migration, remittance, and agricultural productivity: Evidence from the Nepal Living Standard Survey, World Development Perspectives 19 (2020) 100198.

[27] R.K. Sunam, J.F. McCarthy, Reconsidering the links between poverty, international labour migration, and agrarian change: critical insights from Nepal, Journal of Peasant Studies 43(1) (2016) 39-63.

[28] CBS, Nepal - Nepal Living Standards Survey 2010-2011 NLSS Third, in: C.B.o. Statistics (Ed.) CBS, 2011.

[29] E.L. Rhodes, R. Dreibelbis, E.M. Klasen, N. Naithani, J. Baliddawa, D. Menya, S. Khatry, S. Levy, J.M. Tielsch, J.J. Miranda, C. Kennedy, W. Checkley, Behavioral attitudes and preferences in cooking 
Bharadwaj, Bishal, David Pullar, Long Seng To, and Jon Leary. "Why Firewood? Exploring the CoBenefits, Socio-Ecological Interactions and Indigenous Knowledge Surrounding Cooking Practice in Rural Nepal." Energy Research \& Social Science, https://doi.org/10.1016/i.erss.2021.101932 (accepted manuscript)

practices with traditional open-fire stoves in Peru, Nepal, and Kenya: implications for improved cookstove interventions, Int J Environ Res Public Health 11(10) (2014) 10310-26.

[30] H. Sidky, Seized by Spirits: The Jhakri's Calling, Initiation and Training, Haunted by the Archaic Shaman: Himalayan Jhākris and the Discourse on Shamanism, Lexington Books, Lanham, MD, 2008. [31] N. Labanca, P. Bertoldi, Beyond energy efficiency and individual behaviours: policy insights from social practice theories, Energy Policy 115 (2018) 494-502.

[32] A. Nadia, B. Nicola, Determinants of households' investment in energy efficiency and renewables: evidence from the OECD survey on household environmental behaviour and attitudes, Environmental Research Letters 10(4) (2015) 044015.

[33] M. Giri, B. Goswami, Determinants of Household's Choice of Fuel for Cooking in Developing Countries: Evidence from Nepal, Journal of Development Policy and Practice 3(2) (2018) 137-154. [34] N. Francesco Fuso, R. Charlotte, B. Youssef, The cost of cooking a meal. The case of Nyeri County, Kenya, Environmental Research Letters 12(6) (2017) 065007.

[35] A.H. Danlami, S.D. Applanaidu, R. Islam, An analysis of household cooking fuel choice: a case of Bauchi State, Nigeria, International Journal of Energy Sector Management 12(2) (2018) 265-283. [36] J.H. Nlom, A.A. Karimov, Modeling Fuel Choice among Households in Northern Cameroon, Sustainability 7(8) (2015) 9989-9999.

[37] J.-M. Baland, F. Libois, D. Mookherjee, Forest Degradation and Economic Growth in Nepal, 2003-2010, Journal of the Association of Environmental and Resource Economists 5(2) (2018) 401439.

[38] J. Joshi, A.K. Bohara, Household preferences for cooking fuels and inter-fuel substitutions: Unlocking the modern fuels in the Nepalese household, Energy Policy 107 (2017) 507-523.

[39] C. Bielecki, G. Wingenbach, Rethinking improved cookstove diffusion programs: A case study of social perceptions and cooking choices in rural Guatemala, Energy Policy 66 (2014) 350-358.

[40] Y. Malakar, C. Greig, E. van de Fliert, Structure, agency and capabilities: Conceptualising inertia in solid fuel-based cooking practices, Energy Research \& Social Science 40 (2018) 45-53.

[41] H.R. Ojha, R. Ford, R.J. Keenan, D. Race, D.C. Vega, H. Baral, P. Sapkota, Delocalizing Communities: Changing Forms of Community Engagement in Natural Resources Governance, World Development 87 (2016) 274-290.

[42] A. Jagadish, P. Dwivedi, In the hearth, on the mind: Cultural consensus on fuelwood and cookstoves in the middle Himalayas of India, Energy Research \& Social Science 37 (2018) 44-51.

[43] D. Bajracharya, Fuel, food or forest? Dilemmas in a Nepali village, World Development 11(12) (1983) 1057-1074.

[44] M. Cote, A.J. Nightingale, Resilience thinking meets social theory, Progress in Human Geography 36(4) (2011) 475-489.

[45] R. Reyes, H. Nelson, F. Navarro, C. Retes, The firewood dilemma: Human health in a broader context of well-being in Chile, Energy for Sustainable Development 28 (2015) 75-87.

[46] M.J. Herington, Y. Malakar, Who is energy poor? Revisiting energy (in)security in the case of Nepal, Energy Research \& Social Science 21 (2016) 49-53.

[47] N.J. Goodwin, S.E. O'Farrell, K. Jagoe, J. Rouse, E. Roma, A. Biran, E.A. Finkelstein, Use of behavior change techniques in clean cooking interventions: a review of the evidence and scorecard of effectiveness, J Health Commun 20 Suppl 1(sup1) (2015) 43-54.

[48] A. Dhakal, R.K. Rai, Who Adopts Agroforestry in a Subsistence Economy?-Lessons from the Terai of Nepal, Forests 11(5) (2020).

[49] W. Foell, S. Pachauri, D. Spreng, H. Zerriffi, Household cooking fuels and technologies in developing economies, Energy Policy 39(12) (2011) 7487-7496. 
Bharadwaj, Bishal, David Pullar, Long Seng To, and Jon Leary. "Why Firewood? Exploring the CoBenefits, Socio-Ecological Interactions and Indigenous Knowledge Surrounding Cooking Practice in Rural Nepal." Energy Research \& Social Science, https://doi.org/10.1016/j.erss.2021.101932 (accepted manuscript)

[50] Y. Malakar, C. Greig, E. van de Fliert, Resistance in rejecting solid fuels: Beyond availability and adoption in the structural dominations of cooking practices in rural India, Energy Research \& Social Science 46 (2018) 225-235.

[51] J.J. Lewis, S.K. Pattanayak, Who Adopts Improved Fuels and Cookstoves? A Systematic Review, Environmental Health Perspectives 120(5) (2012) 637-645.

[52] F.W. Geels, B.K. Sovacool, T. Schwanen, S. Sorrell, Sociotechnical transitions for deep decarbonization, Science 357(6357) (2017) 1242-1244.

[53] B. van der Kroon, R. Brouwer, P.J.H. van Beukering, The energy ladder: Theoretical myth or empirical truth? Results from a meta-analysis, Renewable and Sustainable Energy Reviews 20 (2013) 504-513.

[54] V. Joon, A. Chandra, M. Bhattacharya, Household energy consumption pattern and sociocultural dimensions associated with it: A case study of rural Haryana, India, Biomass \& Bioenergy 33(11) (2009) 1509-1512.

[55] M. Khandelwal, M.E. Hill, P. Greenough, J. Anthony, M. Quill, M. Linderman, H.S. Udaykumar, Why Have Improved Cook-Stove Initiatives in India Failed?, World Development 92 (2017) 13-27. [56] Y. Malakar, Studying household decision-making context and cooking fuel transition in rural India, Energy for Sustainable Development 43 (2018) 68-74.

[57] O. Akintan, S. Jewitt, M. Clifford, Culture, tradition, and taboo: Understanding the social shaping of fuel choices and cooking practices in Nigeria, Energy Research \& Social Science 40 (2018) 14-22. [58] K.N. Williams, J.L. Kephart, M. Fandino-Del-Rio, L. Condori, K. Koehler, L.H. Moulton, W. Checkley, S.A. Harvey, C.t. Investigators, Beyond cost: Exploring fuel choices and the socio-cultural dynamics of liquefied petroleum gas stove adoption in Peru, Energy Res Soc Sci 66 (2020) 101591. [59] S. Levin, T. Xepapadeas, A.S. Crepin, J. Norberg, A. De Zeeuw, C. Folke, T. Hughes, K. Arrow, S. Barrett, G. Daily, P. Ehrlich, N. Kautsky, K.G. Maler, S. Polasky, M. Troell, J.R. Vincent, B. Walker, Social-ecological systems as complex adaptive systems: modeling and policy implications, Environment and Development Economics 18(2) (2013) 111-132.

[60] F. Riva, H. Ahlborg, E. Hartvigsson, S. Pachauri, E. Colombo, Electricity access and rural development: Review of complex socio-economic dynamics and causal diagrams for more appropriate energy modelling, Energy for Sustainable Development 43 (2018) 203-223.

[61] C. Wilson, H. Dowlatabadi, Models of decision making and residential energy use, Annual Review of Environment and Resources 32(1) (2007) 169-203.

[62] N. Magnani, A. Vaona, Access to electricity and socio-economic characteristics: Panel data evidence at the country level, Energy 103 (2016) 447-455.

[63] B.K. Sovacool, J. Axsen, S. Sorrell, Promoting novelty, rigor, and style in energy social science: Towards codes of practice for appropriate methods and research design, Energy Research \& Social Science 45 (2018) 12-42.

[64] M.J. Westgate, N.R. Haddaway, S.H. Cheng, E.J. McIntosh, C. Marshall, D.B. Lindenmayer, Software support for environmental evidence synthesis, Nat Ecol Evol 2(4) (2018) 588-590.

[65] D. Hamburger, J. Jaeger, P. Bayer, R. Kennedy, J. Yang, J. Urpelainen, Shades of darkness or light? A systematic review of geographic bias in impact evaluations of electricity access, Energy Research \& Social Science 58 (2019) 101236.

[66] U. Dhakal, Inventory of Innovative Indoor Smoke Alleviating Technologies in Nepal, PRACTICAL ACTION NEPAL 2007.

[67] L.G. Hooper, Y. Dieye, A. Ndiaye, A. Diallo, C.S. Sack, V.S. Fan, K.M. Neuzil, J.R. Ortiz, Traditional cooking practices and preferences for stove features among women in rural Senegal: Informing improved cookstove design and interventions, PLoS One 13(11) (2018) e0206822.

[68] V. Rai, D.C. Reeves, R. Margolis, Overcoming barriers and uncertainties in the adoption of residential solar PV, Renewable Energy 89 (2016) 498-505. 
Bharadwaj, Bishal, David Pullar, Long Seng To, and Jon Leary. "Why Firewood? Exploring the CoBenefits, Socio-Ecological Interactions and Indigenous Knowledge Surrounding Cooking Practice in Rural Nepal." Energy Research \& Social Science, https://doi.org/10.1016/j.erss.2021.101932 (accepted manuscript)

[69] J.A. Oldekop, K.R.E. Sims, M.J. Whittingham, A. Agrawal, An upside to globalization: International outmigration drives reforestation in Nepal, Global Environmental Change-Human and Policy Dimensions 52 (2018) 66-74.

[70] T.P. Barakoti, Growth of Uttis (<i>Alnus nepalensis</i>) monitored in a trial plantation at Pakhribas, Dhankuta, Nepal Banko Janakari 16(1) (2006) 41-45.

[71] R.P. Neupane, K.R. Sharma, G.B. Thapa, Adoption of agroforestry in the hills of Nepal: a logistic regression analysis, Agricultural Systems 72(3) (2002) 177-196.

[72] P.S. Chapagain, Firewood management practice by hoteliers and non-hoteliers in Langtang valley, Nepal Himalayas, The Geographical Journal of Nepal 10 (2017) 55-72.

[73] R.P. Neupane, G.B. Thapa, Impact of agroforestry intervention on soil fertility and farm income under the subsistence farming system of the middle hills, Nepal, Agriculture Ecosystems \& Environment 84(2) (2001) 157-167.

[74] K. Maden, R. Kongren, T.M. Limbu, Documentation of Indigenous Knowledge, Skill and Practices of Kirata Nationalities with Special Focus on Biological Resources

[75] S. Sharma, R. Bajracharya, B. Sitaula, Traditional Knowledge in Nepal - A review, Indian Journal of Traditional Knowledge 8 (2009) 569-576.

[76] D. Shrestha, Indigenous vegetables of Nepal for biodiversity and food security, International Journal of Biodiversity and Conservation 5 (2012) 98-108.

[77] P. Sharma, TraditionalIndigenous Practice in different States of India: A Solution for Increasing Pollution of chemical Pesticide, International Archive of Applied Sciences and Technology 9(2) (2018) 7-14.

[78] N.R. Dahal, T.B. Karki, B. Swamylingappa, Q. Li, G. Gu, Traditional Foods and Beverages of Nepal-A Review, Food Reviews International 21(1) (2005) 1-25.

[79] K.R. Smith, Other Remedies, Biofuels, Air Pollution, and Health, Springer US, Boston, MA, 1987, pp. 317-340.

[80] AEPC, Improved Cooking Stoves, 2019. https://www.aepc.gov.np/improved-cooking-stoves. (Accessed 2019/10/01 2019).

[81] A.A. Degen, M. Kam, S.B. Pandey, C.R. Upreti, S. Pandey, P. Regmi, Transhumant Pastoralism in Yak Production in the Lower Mustang District of Nepal, Nomadic Peoples 11(2) (2007) 57-85.

[82] S. Aryal, T.N. Maraseni, G. Cockfield, Sustainability of transhumance grazing systems under socio-economic threats in Langtang, Nepal, Journal of Mountain Science 11(4) (2014) 1023-1034.

[83] J. Hollada, K.N. Williams, C.H. Miele, D. Danz, S.A. Harvey, W. Checkley, Perceptions of Improved Biomass and Liquefied Petroleum Gas Stoves in Puno, Peru: Implications for Promoting Sustained and Exclusive Adoption of Clean Cooking Technologies, Int J Environ Res Public Health 14(2) (2017) 182.

[84] I. Ruiz-Mercado, O. Masera, H. Zamora, K.R. Smith, Adoption and sustained use of improved cookstoves, Energy Policy 39(12) (2011) 7557-7566.

[85] A. Grêt-Regamey, S.H. Huber, R. Huber, Actors' diversity and the resilience of social-ecological systems to global change, Nature Sustainability 2(4) (2019) 290-297.

[86] J.A. Oldekop, K.R.E. Sims, B.K. Karna, M.J. Whittingham, A. Agrawal, Reductions in deforestation and poverty from decentralized forest management in Nepal, Nature Sustainability 2(5) (2019) 421428.

[87] S. Zakkak, E. Kakalis, A. Radovic, J.M. Halley, V. Kati, The impact of forest encroachment after agricultural land abandonment on passerine bird communities: The case of Greece, Journal for Nature Conservation 22(2) (2014) 157-165.

[88] M. Pokhrel, Is wildlife conservation a victim of its own success in Nepal?, Nepali Times, Himalmedia Pvt Ltd, Lalitpur Nepal, 2019. 
Bharadwaj, Bishal, David Pullar, Long Seng To, and Jon Leary. "Why Firewood? Exploring the CoBenefits, Socio-Ecological Interactions and Indigenous Knowledge Surrounding Cooking Practice in Rural Nepal." Energy Research \& Social Science, https://doi.org/10.1016/i.erss.2021.101932 (accepted manuscript)

[89] M.A. Jeuland, S.K. Pattanayak, Benefits and costs of improved cookstoves: assessing the implications of variability in health, forest and climate impacts, PLoS One 7(2) (2012) e30338. [90] J.M. Baland, P. Bardhan, S. Das, D. Mookherjee, R. Sarkar, The environmental impact of poverty: evidence from firewood collection in rural Nepal, Econ Dev Cult Change 59(1) (2010) 23-61. [91] A.D. Foster, M.R. Rosenzweig, Economic growth and the rise of forests, Quarterly Journal of Economics 118(2) (2003) 601-637.

[92] J. Baynes, J. Herbohn, C. Smith, R. Fisher, D. Bray, Key factors which influence the success of community forestry in developing countries, Global Environmental Change-Human and Policy Dimensions 35 (2015) 226-238.

[93] F. Schuenemann, S. Msangi, M. Zeller, Policies for a Sustainable Biomass Energy Sector in Malawi: Enhancing Energy and Food Security Simultaneously, World Development 103 (2018) 14-26. [94] A. Agrawal, Indigenous knowledge and the politics of classification, International Social Science Journal 54(3) (2002) 287-+.

[95] V. Rai, S.A. Robinson, Agent-based modeling of energy technology adoption: Empirical integration of social, behavioral, economic, and environmental factors, Environmental Modelling \& Software 70 (2015) 163-177.

[96] T. Urmee, E. Walker, P.A. Bahri, G. Baverstock, S. Rezvani, W. Saman, Solar water heaters uptake in Australia - Issues and barriers, Sustainable Energy Technologies and Assessments 30 (2018) 11-23. 